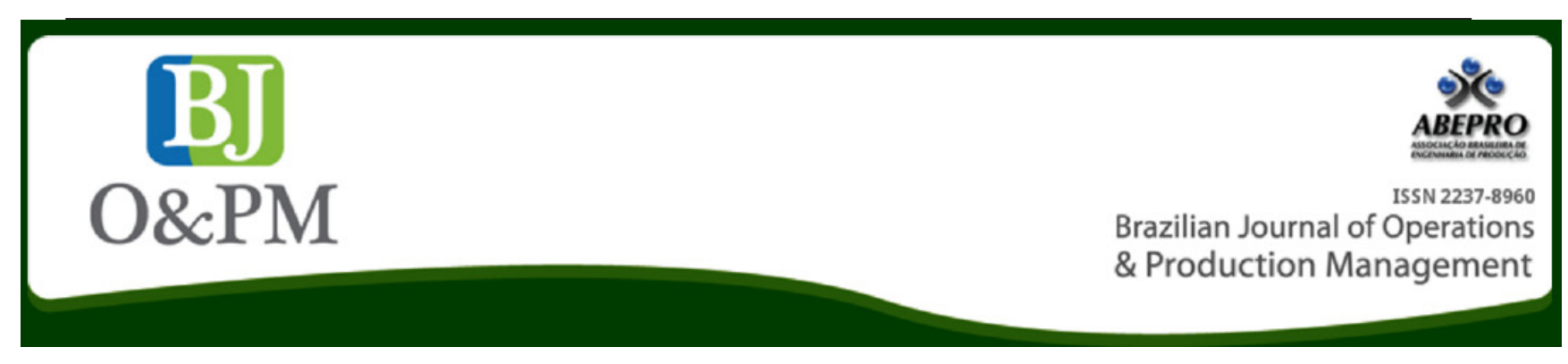

\title{
LEAN HEALTHCARE APPLICATION IN A SURGICAL PROCEDURES APPOINTMENT SCHEDULING CENTER IN A MATERNITY
}

\author{
Rafael Paima; Amanda Costa; Jonathan de Carvalho ${ }^{\text {; }}$ Inácio Araripe Costa Lima ${ }^{c}$

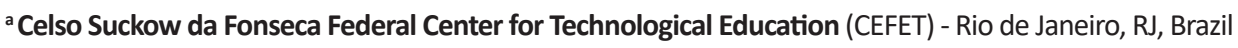 \\ ${ }^{b}$ University of Michigan (UM) - Ann Arbor, MI , EUA \\ ${ }^{\mathrm{c}}$ Thames Valley University (TVU) - London, UK
}

\section{ABSTRACT}

The study aimed to apply Lean Healthcare concepts and tools in surgical scheduling process. The intention was to structure and implement an appointment-scheduling central that was able to manage more effectively the demand for elective obstetrical surgeries in a neonatal maternity. The study used action research as a scientific method in order to solve a problem encountered in scheduling procedures involving employees in a cooperative and participatory improvement initiative. The method used was based on literature review, benchmarking visits and studies to identify good practices, and on current working condition analysis and comparison of indicators before and after the intervention. The Lean and TOC theoretical frameworks was used to improve the process, creating value for the patients and professionals, conducting rootcause analysis, identifying wastes and constrains, and proposing and implementing solutions. Using action research in the study and applying the concepts and tools was possible to reach different results as the $70 \%$ reduction in cancellations, the increase in the number of procedures scheduled in the units, and increased $97 \%$ level of appointment scheduling service among other results.

Keywords: Lean; Healthcare; Centralized Appointment Scheduling; Action Research; Maternity. 


\section{INTRODUCTION}

\subsection{The Relevance of Applying Lean to Healthcare Surgical Procedures Scheduling}

Effective scheduling systems are able to adjust demand to capacity, so that resources are used in the best possible way and patient waiting times are minimized (CAYIRLI; VERAL, 2003). In health systems and services units, the effectiveness of the centralized appointment scheduling has high importance for the care effectiveness and for a more efficient use of resources. A centralized appointment scheduling unit is important to better handle the growing pressure for reducing costs in the healthcare Sector and, at the same time, increase value created to patients and professionals. Scheduling of surgeries has significant relevance because information about surgical demand and capacity must be available to professionals responsible for scheduling, in order to do not compromise the quality of care, to meet medical satisfaction, and to increase the revenue generated by healthcare services.

Demand management enables not only to increase procedures scheduled by physicians, but it enables reduction of negative impacts on health organization processes, such as unavailability of beds at admission and dissatisfaction of patients, professionals and administrators.

In the context of scheduling surgical procedures, the lean approach helps to eliminate or reduce wastes and is present on the principles of the Toyota Production System, later called Lean Thinking (WOMACK; JONES, 1996). In this context, TPS seeks higher quality linked to efficiency, flow, value and generates results in terms of operational excellence in any production system.

This study aimed to apply Lean Healthcare concepts and tools in surgical scheduling process. The intention was to structure and implement an appointment-scheduling central in order to manage more effectively the demand for elective obstetrical surgeries in a neonatal maternity. And thus meet both "medical clients" and "patients-clients" in a more agile and trustable way with safety and effectiveness in patient care and with better overall provision of health services.

The purpose of the application was to contribute to the reduction of waiting for the "doctor or medical client" and to the standardization of procedures related to appointmentscheduling central, considering the need for increase patient safety. The study had the following specific objectives:

- Conduct a literature review about Lean Thinking and its application in the service sector in order to show the benefits of its use in the health sector, resulting in a better understanding of Lean Healthcare;

- Map and understand the process of the surgical procedures appointment-scheduling, from the call made by the "physician customer" to the transfer of patient information to foster his or her health security;

- $\quad$ Define what is the value created by the scheduling process to support better identification and classification of existing waste from the perspective of Lean Thinking concepts and tools;

- Use Visual Management tool, specifically, a frame, called Heijunka based in the forth Toyota Principle (Balance demand and capacity to generate flow), useful to leveling of demand and surgical capacity, and present it to the team involved in process, in order to demonstrate the benefits of its use when considering monitoring of day-to-day work, the elimination or reduction of waste, to identify problems and to propose and implement solutions;

- $\quad$ Reduce waiting time and lead time to perform the scheduling process and to improve the usage of the resources involved in surgery and increase procedures executed as scheduled, i.e. decrease cancelations and rework;

- To evaluate the results of the application of Lean Healthcare in order to analyze the impacts in the performance and time consumption.

The study was conducted by professionals from the unit-sector responsible for appointment-scheduling, with the support of nurses and technicians that were previously responsible for the scheduling of surgeries before the central was created and implemented. These professionals, supported by an internal unit specialized in Lean and improvement concepts and techniques, were involved in the understanding of the current state analysis (as-is analysis) and in the consolidation of all relevant information to design the new scheduling central. The interaction and involvement of professionals was important not to compromise the medical customer satisfaction.

The relevance of the work is presented by highlighting the benefits of applying Lean Thinking and use it to reduce waiting times, increase of scheduled procedures executed as scheduled and broadening the perception of "medical clients", regarding the possibility of having a well-structured process, regardless of personalized care before the central was implemented.

Hospitals shall have significant interest in this article, since the appointment of procedures is a common problem for healthcare organizations. Proper scheduling is of interest not only to healthcare professional, but also to health insurance companies, health organizations and, of course, to patients.

Another importance is related to the financial waste that takes place when you cannot manage properly surgical 
appointments, ignoring demand peaks and valleys, and thus procedures are scheduled without visibility of the greater restriction of maternity, which is the availability of beds.

The work, in addition to this introduction, presents a review of literature on the health sector, the particularities of hospitals, on central appointment-scheduling, on Lean Thinking and on Lean Healthcare concepts and tools. Subsequently, methodological procedures are presented, with the description of the study context and how actions taken during the intervention in the presented problem.To conclude, they performed the analysis of the results and final considerations are presented.

\section{LITERATURE REVIEW}

Porter et Teisberg (2007) state that is strategic to improve quality and reduce health care costs. Christensen et al., (2009) state that the health is a key sector to object of disruptive innovation concepts, in order to contribute to the change of care.

Rechel (2010) was responsible for a study of the World Health Organization (WHO) that highlights the importance of innovation in the management of beds and shows how better plans and services schedules are important part of thisefficient trajectory. Moreover, Rechel et Souza's studies show papers concentration in the USA, UK and fewer studies in developing countries. (SOUZA, 2009; RECHEL, 2010).

This session presents characteristics of the frames and concepts of process management to promote improvements, studies and Lean and Lean Healthcare health sector tools and, finally, highlights concepts of scheduling centrals.

\subsection{Conceptual Frames to Promote Improvement: Emphasis on Lean}

This topic discusses conceptual frameworks as a way to highlight the promotion of improvement through their applications. Although the focus is for Lean Thinking, we approach the Theory of Constraints to conceptualize restrictions identified in the process.

\subsubsection{Lean Thinking}

Developed by Ohno (1997) by competition in an unstable scenario and supported the exclusion of wastes, to improve the organization of Toyota, unpredictable processes and slow economic growth, comes the Lean Thinking.

Lean thinking (WOMACK; JONES, 1996) from the Toyota Production System (OHNO, 1988) focuses on the following principles: setting value for the customer, value chain management, establish continuous flow technique driven production and the constant search for perfection.

The principles mentioned are operated by a variety of means; one of the most common is the elimination of waste (LIKER; MEIER, 2006). These principles can be applied in various industries, including health (CHALICE, 2007; GRABAN, 2009; SPEAR, 2005).

According to Womack and Jones (1994), by eliminating unnecessary steps, aligning all the steps of an activity in a continuous stream, recombining work in cross-functional teams, and continually striving for improvement, companies can develop, produce and distribute products with half or less of human endeavor, space, tools, time and overall costs. They can also become much more flexible and responsive to customer desires.

Some examples of health wastes can be related to reduce errors (GROUT; TOUSSAINT, 2010), reduction of waiting times (GIJO et al., 2013), reduced patient travel time to the hospital (CHIARINI, 2013) and improvements in information systems (LAZARUS; ANDELL, 2006).

The starting point for implementation of Lean Thinking and consequently obtain the presented results is the correct setting value. For Womack et Jones (2004), the value should be set by the customer, not the organization, making customer needs become priorities and requirements for the construction of the product / service with a specific price. What the customer is not willing to pay will be characterized as waste and eliminated. Customer satisfaction is linked to their perception of value, because the higher their perception, the greater its adhesion to the product / service.

Ohno (1997), an engineer at Toyota, ranked waste in seven groups:

$$
\begin{aligned}
& \text { 1-Waste on overproduction; } \\
& \text {-Waste on waiting; } \\
& \text { 3-Waste on transport; } \\
& \text { 4-Waste in processing; } \\
& \text { 5-Waste on inventory; } \\
& \text { 6-Waste on movement; } \\
& 7 \text { - Waste on defects or rework. }
\end{aligned}
$$

We can also cite an eighth waste recognized for lean production as "waste of employee creativity" characterized as a waste for the organization related to the time, knowledge, ideas, skills and opportunities for improvement not involve the employee.

Some authors also address the waste of natural resources and infrastructure. This type of waste is very present in organizations, including in health, with excessive use of space, power, equipment and resources in general.

Many countries have noticed the increasing cost curve, without significant improvements in health. However, there is a need for intervention in order to provide the 
Brazilian Journal of Operations \& Production Management

Volume 13, Número 4, 2016, pp. 452-461 DOI: 10.14488/BJOPM.2016.v13.n4.a5

best assistance linked to lower cost. The concepts and Lean Healthcare and tools feature as a way to achieve this. The Theory of Constraints can be another method to achieve this goal (GOLDRATT, 1990; GOLDRATT; COX, 1992).

\subsubsection{Lean Thinking and Theory of Constraints}

The Theory of Constraints - TOC is a management philosophy that aims to improve systems (SOARES et al., 2006). TOC brings the concept of processes associated with the identification of constraints, defined as activities or processes that limit business performance (GOLDRATT, 1993 STEIN, 1996 et UMBLE et SRIKANTH, 1990, 1997a 1997b).

To identify a restriction, it is necessary to have an articulated overview of the entire process. This view is constructed from a network (STEIN, 1996; SHINGO 1996; ANTUNES, 1998) representing resources, products, etc.

In this context, it is possible to propose the integration of the techniques of Theory of Constraints (TOC) and the Toyota Production System (TPS) (ANTUNES, 1998). The logic of the combination is centered on the idea that it is necessary to understand a transverse process, which passes through various areas and/or operations, to identify the main restrictive point.

Logic "understand to identify" comes, mainly, the Theory of Constraints to the idea bottleneck, and the Toyota Production System (TPS), with the idea of network operations and processes. This hybrid logic processes improvements by reducing variability and increasing flexibility and timing from the restricting action (ANTUNES, 1998).

According to Dettmer (2001), TOC and Lean evolved to a systemic view of philosophy and suggest that the hybrid model of the two approaches is more robust, productive and easier to implement and the main aspect is the selection of aspects of the model.

This article highlights the use of these combined models, using Lean to eliminate wastes and TOC to the restriction of management.

\subsection{Lean Healthcare Concepts and Tools}

According to Souza (2009), the first studies on Lean Healthcare were reported by Heinbuch (1995) with emphasis on the use of JIT to reduce inventories in hospitals. Jacobs and Pelfrey (1995) and Whitson (1997) also used production management concepts in the healthcare industry. Souza (2009) presents a historical trajectory of publications Lean Healthcare. The application of study in the automotive industry, in the 40s, with the emergence of STP passed by Lean use in operations management from the 80 s, says the service sector as the object of Lean application, as with adaptations, and ends with the focus on health, particularly in hospitals and formalizes the name of Lean healthcare.
Souza (2009) highlights important publications of the NHS from 2001 studies, such as the Chalice $(2005,2007)$, Zidel (2006), Joint Commission (2006) and Smith et al., (2008), highlight the applicability and the need to adapt to the particular complexity of the health sector. This study, according to the classification proposed by Souza (2009), falls as a case study, not speculative, and focused on patient flow, with emphasis on management and support.

The expression "Lean Healthcare" gained more notoriety from important authors of the Institute for Healthcare Improvement, led by Diane Miller, with later studies Spear (2005) et Jones and Filochowski (2006). Case studies have been presented as a methodological approach to testing the validity of Lean concepts in healthcare environments. Silvester et al. (2004), Jimmerson, Ghosh et Sobek (in different jobs together) present case studies, principles and evidence of tools being applied in Health Studies such as Bahensky et al. (2005); Workman-Germann and Haag (2007); Viau and Southern (2007) show financial benefits in specific health services, such as radiology (SOUZA, 2009).

One of the most prominent case studies was carried out by Furman (2005) at Virginia Mason Hospital in Seattle. This hospital was visited three times by the authors of this article, benchmarking and training actions. The literature in book and article on the lessons learned was also consulted (KENNEY, 2001).

In developing countries, there are initial studies, but there is still shortage of literature. Miller (2015) presents a study with use of Lean tools to increase the value created and reduce the discharge of patients while in an Indian hospital.

In Brazil, Correa et al. (2005) highlights the lean healthcare as a technological solution to monitor the flow of patients in hospitals. Silberstein (2006) reviews the concepts and results of pilots in Brazil (Souza, 2009). Pinto (2015), in his study of post-doctorate, discovers that Omachonu (1991) already distinguished hospitals manufactures and Bowen and Youngdahl (1998) were pioneers in addressing the operation (production system) of a hospital in the view of lean principles.

The work of Souza (2009) does not identify Lean applications for scheduling plants. In our bibliographical review, there are eight articles on central and thirty articles on Lean as a basis for scheduling units design.

Articles guided the application of the concepts and the use of tools. One of the Lean tools used in structuring the Scheduling Center was the Visual Management, also described as visual control. The management to view underlies increasing effectiveness of operations in a process, making noticeable, consistent and intuitive things (PINTO, 2009). 
B Brazilian Journal of Operations \& Production Management

Volume 13, Número 4, 2016, pp. 452-461

DOI: 10.14488/BJOPM.2016.v13.n4.a5
Liker (2008) described 14 Toyota Principles. The forth principle states that demand must be balanced with the capacity, generating flow. Many of the companies appeal to management in sight to assist communication and information indispensable within sight of all, because when things are visible they remain in our mind, becoming necessary to decision making processes, making them simpler. Visual managements favor the necessary information to taxpayers (PINTO, 2006).

\subsection{Surgical Appointments Scheduling Centers}

Centralizing the schedule has already been reported in 2004 as able to increase the satisfaction of physicians and improve efficiency in a radiology department, but the study was not scientific rigor and was published by Lawrence (2004). Time reduction gains were identified, revenue growth, cost reduction and greater efficiency of radiology services. Simon and Canacari (2014) reported a case of scheduling surgical procedure, describing the methodological procedures and results.

Siek (2008) reports the use of scheduling technology to improve efficiency and simultaneously better allocate teams to have more effective services in Hays hospital in the US.

Warner et al. (2013) used Lean and Six Sigma to reduce working hours and increase the amount of vascular surgery at the scheduled ending time. The same study reports combined cost reduction with increased quality and effectiveness of surgical procedures.

Huddle et al. (2016) use combined with Lean Six Sigma for the schedules of audiology with reduced wastes and variability in a tertiary unit. The study stands out for evidence simply the use of Value Stream Mapping tool to show what has changed with the introduction of a central scheduling and highlight the benefits of implementing the changes.

\section{METHODOLOGY: ACTION RESEARCH USED TO APPLY LEAN TO A MATERNITY SCHEDULING CENTRAL}

This study used action search as a research method in order to solve a problem encountered in scheduling procedures involving employees of cooperative and participatory manner. Waring and Alexander (2015) use action research to study the flow of patients to beds integrated management. Mazzocato et al. (2012) reported an application of Lean with use of single case study technique in a pediatric hospital.

The purpose of action research is to modify a situation after an intervention. Action research analyzes, evaluates and proposes changes to the participants in order to improve previous practice (SEVERINO, 2007). This action research has analyzed the appointment process, evaluate it and better alternatives from benchmarking and propose as solution a centralized scheduling unit.

One can also understand the purpose of the use of action research, for example, involve people in the case study of the problems and seek a working group eager for change and accompanying the actions taken (LIMA, 2007).

The method used was based on benchmarking visits and studies to identify good market practices, the current working condition analysis and comparison of indicators before and after the intervention. We collected qualitative data through observation of the professionals who made the markings of internal procedures and documents to understand the actual work process. Then the results of applying the concepts related to conceptual frameworks were analyzed in order to understand how the intervention worked, and identify strengths and considerations for future improvements.

These steps work construction consisted of literature to consolidate the theoretical framework of conceptual frameworks to promote improvement as Lean and TOC, setting value for the customer, identifying the causes of wastes and restrictions, proposition and implementation of solutions.

\subsection{Study Context}

Created in 1993, the Perinatal Group is the market leader maternity in Rio de Janeiro, with $78 \%$ market share. Maternity Perinatal is a pioneer in private sector hospitals with maternity profile for full service to pregnant women and newborns. Perinatal has several national recognitions as the best maternity in Brazil.

Since it was founded, more than one hundred thousand births were performed, with survival rates and clinical indices that surpass indicators of more developed countries. Motherhood carries an average of 15,000 annual births. The Perinatal has 151 adult beds and 92 beds in intensive care units (NICU), spread into two units - Bar and Orange - and five neonatal cells in other state hospitals.

In 2009, the Perinatal Group joined the Group Santa Joana and Pro Matre Paulista, Sao Paulo, making it the largest private network of maternity Brazil.

By studying the growth of units of Perinatal, you can see a paradigm of the search for the delivery of healthcare services with excellence and recognition, but, on the other hand, with less concern for procedural structure and efficiency in the delivery of these services.

Like many hospitals, by 2013, all procedures of Perinatal Group were scheduled within the same surgical center of its units, by phone or in person. Nurses and techniques took turns attending nursing calls, checking room availability of 
jobs, canceling or reserving schedules, as they watched the proceedings and assisted the clinical staff in the operating rooms. For more than strove, the primary focus of nursing was not the schedule and, after, assistance.

The medical care provided to the client, which sought to schedule a procedure was personalized, and their quality of service linked to the professional who performed the schedule. Non-standard care resulted in the physician dissatisfaction. Sometimes the service was chaotic, especially in the intense peak hours in the operating room. Errors in the data completing the procedure and the patient were common, increasing the risk to the health of the patient and the dissatisfaction of doctors.

This scenario shows the need for an entire physical structure, process and results to ensure a quality service to a clientele of doctors who support the business, with the completion of its procedures in the units.

Thus, it can be noted that ensuring the full functioning of the scheduling industry is essential in order to enable scheduling safe, efficient and effective.

\subsection{Application of Lean Thinking in Perinatal Maternity}

The first step in applying the Lean Thinking was to understand the customer process and needs and to consolidate the definition of value for Perinatal's Patients.

By understanding that the main customer was the medical professional responsible for referring patients to perform their procedures, it was possible to define value as the standard service, at the right time and with sufficient information to meet customer demand without compromising the security of your patient.

From this understanding, it was possible to identify several types of wastes and Lean waste which compromised customer satisfaction and generated direct and indirect financial impacts.

Procedural error occurrences in gathering scheduling information and inputting it in system were common. Transfers and cancellations were treated as synonyms, generating indicators that did not represent the actual demand, impacting the sector management and the hospital. This "defect waste" created difficultiestoo, for example, implementing management strategies based on hourly variability of demand Surgical Center, complexity faced by many hospitals in Brazil. A waste like that contributed to have moments of great occupation of operating rooms and were succeeded by other significant idle, generating other wastes. The units surfed from the bullwhip effect (FORRESTER, 1961). We can cite, for example, wastes due to overproduction evidenced in team sizing or staffing and infrastructure wastes on the need for new investments.
As surgeries are part of the services considered less urgent in relation to assistance functions, some intersectorial agreements were not always respected, generating wastes for waiting and handling.

The scheduling process provided not to identify the patient's capacity allocation before and after surgery in hospital and in assisting the patient in his bed. Another waste, related to waiting, could be identified on arrival of the patient. On average, patients waited an hour and a half to be hospitalized generating a moment of anxiety. The lack of agreements generated an unpredictable scenario and constant stress for the other hospitals sectors.

\subsubsection{Perinatal New Process and Demand}

The newly created Perinatal Processes team was designated to relocate the scheduling service procedures outside the operating room. This movement has already demonstrated the failure of a cultural paradigm, which the management of hospital demand should be done within the surgical field. For this reason, the change could not be abrupt, at the risk of further increase of medical customer dissatisfaction and request would be careful and structured planning - another paradigm shift in the hospital environment.

Starting from "true north" Lean Concept given by the Executive Board of Perinatal, were several meetings involving the managers and operational staff of the Surgical Center, in order to engage employees in the change and make them feel belonging to the improvement proposal. They were almost made one hundred hours of observation in the Gemba, trying to understand existing processes and standards and identify opportunities to undo restrictions on surgical scheduling process.

\subsubsection{Benchmarking Visits}

Two benchmarking visits were made in other surgical procedure appointment-scheduling central. The first was in a large maternity São Paulo and the other in a same-size maternity hospital in Rio de Janeiro. In both nurses managed the units, which had classroom experience in the surgical field. The learning in other core processes allowed the team to perfect the positives found, just as the challenges encountered in visitations, made the learning curve to become steeper in a short time.

The importance of monitoring indicators and a need for greater interaction between the scheduling process with the authorization procedures was evident during the visits and became a constant search for improvement to the new station to be built. 


\subsubsection{Actions Implemented}

The table 1 lists the problems identified with the implemented solutions and their benefits in Perinatal.

Table 1 - Constraints, solutions and benefits.

\begin{tabular}{|c|c|c|}
\hline Constraints & Solutions & Benefits \\
\hline $\begin{array}{l}\text { Demand peaks } \\
\text { and idle valleys } \\
\text { in surgery } \\
\text { Center. }\end{array}$ & $\begin{array}{l}\text { Specific management } \\
\text { scheduling, targeted } \\
\text { to level demand; } \\
\text { Indicators creation } \\
\text { success. }\end{array}$ & $\begin{array}{l}\text { Increased number of } \\
\text { procedures; } \\
\text { Demand leveling; } \\
\text { Optimization of capacity } \\
\text { installed supply. }\end{array}$ \\
\hline $\begin{array}{l}\text { Process } \\
\text { scheduling } \\
\text { personalize } \\
\text { and inadequate } \\
\text { care. }\end{array}$ & $\begin{array}{l}\text { Scheduling process } \\
\text { standardized, } \\
\text { professional, } \\
\text { customized and agile. }\end{array}$ & $\begin{array}{l}\text { Reduction of risks } \\
\text { associated with scheduling } \\
\text { process; } \\
\text { Operating tranquility; } \\
\text { Increased customer } \\
\text { satisfaction. }\end{array}$ \\
\hline $\begin{array}{l}\text { Scheduling } \\
\text { oriented } \\
\text { demand } \\
\text { according } \\
\text { to idleness } \\
\text { to operating } \\
\text { rooms. }\end{array}$ & $\begin{array}{l}\text { Demand scheduling } \\
\text { oriented according } \\
\text { to occupation of } \\
\text { beds (adequacy of } \\
\text { management place in } \\
\text { the restriction). }\end{array}$ & $\begin{array}{l}\text { Operating tranquility; } \\
\text { Length of stay reduction the } \\
\text { patient; } \\
\text { Predictability of demand } \\
\text { future. }\end{array}$ \\
\hline $\begin{array}{l}\text { Interruptions at } \\
\text { work of nursing. }\end{array}$ & $\begin{array}{l}\text { Reassignment } \\
\text { scheduling to a new } \\
\text { center schedules. }\end{array}$ & $\begin{array}{l}\text { Operating tranquility; } \\
\text { Increased customer } \\
\text { satisfaction. }\end{array}$ \\
\hline $\begin{array}{l}\text { Contingency } \\
\text { plans undefined. }\end{array}$ & $\begin{array}{l}\text { Agreements and } \\
\text { routines intersectoral; } \\
\text { Redesign architecture } \\
\text { telephone. }\end{array}$ & $\begin{array}{l}\text { Increased customer } \\
\text { satisfaction; } \\
\text { Increased capacity } \\
\text { attendance; } \\
\text { Continuity and tranquility } \\
\text { operating. }\end{array}$ \\
\hline
\end{tabular}

Source: The authors own.

During the observations, it was clear the rebound and the unfolding of inadequate demand management in the hospital, generating patient queues at reception waiting for beds that were still occupied.

In analyzing the situation, it was found that scheduled procedures were not related in a standardized way with the availability of beds. While the Surgical Center worked with an average idle capacity of $40 \%$, the rooms on the floors were crowded. Soon, it was realized that the restriction was in the availability of beds and it is who should govern the management of scheduling demand in the Surgical Center.

According to this evidence, intersectoral agreements have been made in the scheduling procedures follow search the availability of vacant rooms. After statistical analysis, which took into account the average stay per procedure, maximum track schedule was established. These scheduling constraints would have to be flexible enough, to be readjusted and readapted if the pattern of demand changes. What enabled flexibility was the adoption of weekly routine meetings between the managers of the operating room, nursing the beds, the hospital and the new Central Schedules.

To equate the risks of interruptions due to the fall of the

telephone network was re-architected strategy telephone signal delivery to the Perinatal, seeking parallel trunks telephony to serve contingency in the case of one of the trunks fail. Allied to this, hired a smart phone system, which transforms the analog telephone transmission of data, or Voice over Internet Protocol (VolP), allowing the same number could meet more than one connection at a time. This same system compiles data that subsequently feed proficiency indicators of telephone service.

For Schedules Center, sought to market a nurse who had experience in the surgical field, as for the schedule was a request understanding of the complexities and idiosyncrasies of each surgical procedure. Under his management, telephone attendants who were trained in immersion in the Surgical Center for 30 dayswere hired

From the observations made in the Surgical Center, it was built a standard script service, ensuring higher quality in scheduling and greater security to the patient. To assist the management of the new plant, in addition to weekly monitoring meetings with the Process team, strategic indicators were established management, displayed on two plasma panels inside the Central.

Table 2 - Scheduling Center indicators.

\begin{tabular}{|c|c|}
\hline \multicolumn{2}{|c|}{ Indicators monitored by Perinatal Schedules Centers } \\
\hline Production Indicators & Indicators Service \\
\hline $\begin{array}{c}\text { Number and participation } \\
\text { procedures elective }\end{array}$ & Incoming calls (daily and monthly) \\
\hline \multirow{2}{*}{$\begin{array}{c}\text { Number and participation } \\
\text { procedures fitting }\end{array}$} & Average waiting time \\
\cline { 2 - 2 } & Average time connection \\
\hline \multirow{2}{*}{$\begin{array}{c}\text { Number and participation } \\
\text { procedures canceled }\end{array}$} & $\begin{array}{c}\text { Performed schedules (daily and } \\
\text { monthly) }\end{array}$ \\
\cline { 2 - 2 } & Schedules x connections \\
\hline $\begin{array}{c}\text { Hourly distribution of } \\
\text { occupation Surgery Center }\end{array}$ & Missed connections \\
\cline { 2 - 2 } & Service level \\
\hline
\end{tabular}

Source: The authors own.

One of the panels shows the production schedules for both units in a daily vision covering 60 days. Following the maximum ranges of agreed schedules, lights and colors determine the schedules and allow attendants greater control of the immediate demand and better management in the leveling of future demand. The second panel includes indicators for telephone calls, with the amount of incoming calls, answered and abandoned, and waiting time and queue ID. This view of the indicators generates a better distribution of connections between servers, and provide the management of most of the staff scheduling capacity, working on six hours each scales. Monitoring by the clear indicators has been essential to resolve issues, manage contingencies and to observe demand trends.

\section{RESULTS ANALYSIS}

The post-opening results of schedules Center Perinatal 
were meticulously measured and reflect the success of the venture. There was a considerable increase in the number of procedures in both units, increasing by $17 \%$ the production of the surgical center of the Barra unit (a Rio's Neighborhood is named Barra) and $15 \%$ of the Laranjeiras unit (another Neighborhood).

The results are direct consequence of a leveling of demand, better distributing patients among the peaks and valleys, leading to better utilization of capacity and consequently reduce idleness. There was also a reduction of $70 \%$ of cancellations, allowing better use of operating rooms.

Qualitative results were the same impact, increasing the satisfaction perceived by the "client doctor" with the patientclient, standard and fast service, reaching $97 \%$ of the level of scheduling service. It was increased by $13 \%$ adherence to safe surgery protocol, generating greater safety to the patient and giving the operation of the surgical center more peace of mind operation. Indirectly, the average length of stay of patients decreased by $52 \%$, which allowed an increase in patient satisfaction with the service of reception of $32 \%$ and an overall increase in satisfaction.

\section{FINAL CONSIDERATIONS}

The work was developed with the intention to structure the service of appointment-scheduling surgical procedures of a maternity. The desired result was able to manage more effectively the demand for elective obstetrical surgeries in a neonatal maternity.

The study was developed through activities that encompassed: literature for understanding conceptual frameworks as TPS or Lean and Theory of Constraints in order to highlight the benefits of their use; interaction with professionals responsible for scheduling the Surgical Center to understand the current condition of the processes and think about improvements; use the spot management tool; presentation and implementation of improvements and suggestions for future activities.

Through analysis of the Lean Thinking it was possible to conclude that this has tools and techniques that enable reduction, or even elimination, of activities that do not

They add value to the processes of the health system, i.e., loss and waste. The TOC helps to identify the restrictions to be removed. The identification of wastes and identification of problems could be performed by setting the value would be for the process according to Lean Thinking. Thus, it was possible to identify wastes due to defects, hold, rework and infrastructure, for example.

Applying the concepts and tools made it possible to reach different results as the $70 \%$ reduction of cancellations and the increase in the number of procedures scheduled in the units, and increased $97 \%$ level scheduling service among other results.

It is noteworthy that, although the shares have generated significant results, many challenges are still found. Greater alignment and interaction scheduling procedures with the authorization process with the covenants will bring greater fluidity in bureaucratic procedures and the company's revenues. Optimizing vacancies management is another challenge, as incipient in the national health sector, but with potential for great results in predictability of demand and adequate supply, as seen in examples of civil aviation and the hotel market.But probably the biggest challenge is the persistence in believing and trusting in a new cultural paradigm of thinking about projects in health, in a structured, planned and coordinated, increasing the chances of success and delivering increasingly, a service care excellence.

We highlight the work limitations deployment in only two units of the same group, the researchers were participants and the literature review have focused only on Lean, TOC and Scheduling Centers.

That way we as a contribution to future studies detailed description of the plant operation scheduling and the ability to replicate the model in other hospitals.

Finally, it was concluded that the objective was achievedWith the application of concepts and tools of Lean Thinking and TOC was possible to structure a central schedule that was able to manage the demand for surgeries and thus, contribute to the reduction of waiting for the doctor and client and also the standardization of procedures related to central scheduling.

\section{REFERENCES}

ANTUNES, Jr. J. A. V. (1998). Em Direção a uma Teoria Geral de Administração da Produção: Uma Discussão sobre a Possibilidade de Unificação da Teoria das Restrições e da Teoria que Sustenta a Construção dos Sistemas de Produção com Estoque Zero, Tese de Doutorado, UFRGS, Porto Alegre.

BOWEN, D. E. , YOUNGDAHL, W. E. (1998). "Lean” service: in defense of a production line approach", International Journal of Service Industry Management, Vol. 9 Iss: 3, pp.207 - 225.

CAYIRLI, T. \& VERAL, E. (2003). Outpatient Scheduling in Health Care: A Review of Literature, Production and Operation Management, Vol 12, №4, Winter 2003.

CHALICE, R. (2007). Improving Healthcare Quality using Toyota lean Production Methods: 46 Steps for Improvement, 2nd ed., Quality Press, Milwaukee, WI.

CHALICE, R. (2005). Stop Rising Healthcare Costs using Toyota lean Production Methods: 38 Steps for Improvement, Quality Press, Milwaukee, WI. 
Brazilian Journal of Operations \& Production Management Volume 13, Número 4, 2016, pp. 452-461

DOI: 10.14488/BJOPM.2016.v13.n4.a5
CHIARINI, A. (2013). Waste savings in patient transportation inside large hospitals using lean thinking tools and logistics solutions, Leadership in Health Services, Vol. 26 No. 4, pp. 356-367.

CHRISTENSEN, C., GROSSMAN, J.H.; HWANG, J. (2009). The Innovator's Prescription: A Disruptive Solution for Health Care, McGraw-Hill, New York, NY

CORREA, F.A., GIL, M.; BARCOS, L. (2005). Benefits offices connecting RFID and lean principles in health care", available at: http://e-archivo.uc3m.es/dspace/ bitstream/10016/143/1/wb054410.pdf (accessed 15, April 2016).

DETTMER, W. (2001). Beyond Lean Manufacturing: Combining Lean and the Theory of Constraints for High Performance. Goal System Internacional. Port Angeles, WA, USA.

FORRESTER, J. (1961). Industrial Dynamics. MIT Press.

FURMAN, C. (2005). Implementing a patient safety alert system. Nursing Economics, Vol. 23 No. 1, pp. 42-5.

GIJO, E.V.; ANTONY, J.; HERNANDEZ, J.; SCARIA, J. (2013). Reducing patient waiting times in a pathology department using the six sigma methodology, Leadership in Health Services, Vol. 26 No. 4, pp. 253-267.

GOLDRATT, E.M. (1990). What is this thing called the Theory of Constraints? North River Press, Croton-onHudson, NY.

GOLDRATT, E.M.; Cox, J. (1992). The Goal - A Process of Ongoing Improvement. Second Rev. Ed., North River Press Publishing Corporation, Great Barrington, MA. GOLDRATT, E. M., A Meta. 36 ed. Educator, Rio de Janeiro.

GRABAN, M. (2009). Lean Hospitals : Improving Quality, Patient Safety, and Employee Satisfaction. CRC Press Taylor \& Francis Group.

GROUT, J.R.; TOUSSAINT, J.S. (2010). "Mistake-proofing healthcare: why stopping processes may be a good start", Business Horizons, Vol. 53 No. 2, pp. 149-156.

HEINBUCH, S.E. (1995). A case of successful technology transfer to health care: total quality materials managements and just-in-time, Journal of Management in Medicine, Vol. 9 No. 2, pp. 48-56.

HUDDLE, M., TIRABASSI, A.; TURNER, L.; LEE, E.; RIES, K.; SANDRA Y. L. (2016). Application of Lean Sigma to the Audiology Clinic at a Large Academic Center Otolaryngology -- Head and Neck Surgery April 2016 154: 715-719, first published on February 9, 2016.

JACOBS, S.M.; PELFREY, S. (1995). Applying just-in-time philosophy to healthcare, Journal of Nursing Administration, Vol. 25 No. 1, pp. 47-52.
JIMMERSON, C., WEBER, D.; SOBEK, D.K. (2005). "Reducing waste and errors: piloting lean principles at intermountain healthcare", Joint Commission Journal on Quality and Patient Safety, Vol. 31 No. 5, pp. 249-57.

JOINT COMMISSION ON ACCREDITATION OF HEALTHCARE ORGANIZATIONS (2006). Doing More with Less: lean Thinking and Patient Safety in Healthcare, Joint Commission Resources, Oak Brook, IL.

JONES, D.; FILOCHOWSKI, J. (2006). Lean healthcare. Think yourself thin, Health Services Journal, Vol. 16 No. 6, p. 7.

KENNEY, C. (2001). Transforming Health Care: Virginia Mason Medical Center's Pursuit of the Perfect Patient Experience, $1^{\text {ST }}$ Edition, CRC Press.

LAWRENCE, C. (2004). Grand central scheduling: case history: a hospital radiology department gains physician satisfaction and treatment efficiency with a centralized scheduling solution." Health Management Technology Oct. 2004: 50+. Academic OneFile. Web. 30 May 2016.

LAZARUS, I.; ANDELL, J. (2006). Providers, payers and IT suppliers learn it pays to get lean, Managed Healthcare Executive, Vol. 16 No. 2, pp. 34-6.

LIMA, A. C. (2007). Práticas do Pensamento Enxuto em ambientes administrativos: aplicação na divisão de suprimentos de um hospital público. Tese de Doutorado em Engenharia Mecânica, UNICAMP, São Paulo.

LIKER, J.K.; MEIER, D. (2006). The Toyota Way Field book, McGraw-Hill, New York, NY.

MAZZOCATO, P.; HOLDEN, R. J.; BROMMELS, M.; ARONSSON, H.; BÄCKMAN, U.; ELG, M.; THOR, J. (2012). How does lean work in emergency care? A case study of a lean-inspired intervention at the Astrid Lindgren Children's hospital, Stockholm, Sweden. BMC Health Services Research $12,28$.

MILLER, R. (2015). Utilizing lean tools to improve value and reduce outpatient wait times in an Indian hospital. Leadership in health services [1751-1879] vol:28 iss:1 pg:57 $-69$

OHNO, T.O. (1997). Sistema Toyota de Produção - além da produção em larga escala. Porto Alegre: Artes Médicas.

OMACHONU, V. K. (1991). Total Quality and Productivity Management in: Health Care Organizations. American Society for Quality Control and Industrial Engineering and Management Press, p. 298.

PINTO, J. P. O. (2006). Aplicação Lean Thinking: Criar Valor Eliminando Desperdícios. Comunidade Lean Thinking.

PINTO, R. Como os princípios da Produção Enxuta podem contribuir para a alavancagem da performance Econômico- 
Financeira na área da saúde - o Lean Healthcare. http:// www.produttare.com.br/artigos.php?titulo=Como-osPrincipios-da-Producao-Enxuta-podem-contribuir-para-aAlavancagem-da-Performance-Economico-Financeira-naarea-da-Saude---o-Lean-Healthcare-, acessado em 14 de março de 2016.

PORTER, M.E.; TEISBERG, E.O. (2007). Redefining Health Care: Creating Value-Based Competition on Results, Harvard Business School Press, Boston, MA.

SEVERINO, A. J. (2007). Metodologia do Trabalho Científico. Editora Cortez, São Paulo.

SILVESTER, K., et. el. (2004). Reducing waiting times in the NHS: is lack of capacity the problem? Clinician in Management, Vol. 12 No. 3, pp. 1-5.

SHINGO, S. (1996). O Sistema Toyota de Produção: do ponto de vista da engenharia de produção. 2. ed. Porto Alegre: Bookman.

SIEK, T. (2008). Superior scheduling: a Midwestern provider adopts automated scheduling to enhance efficiency while ensuring appropriate staffing for effective healthcare. Health Management Technology Jan. 2008: 24+. Academic OneFile. Web. 30 May 2016.

SILBERSTEIN, A.C.L. (2006). Um estudo de casos sobre a aplicação de princípios enxutos em serviços de saúde no Brasil, Master's thesis, Universidade Federal do Rio de Janeiro, Rio de Janeiro.

SIMON, R. W.; CANACARI, E. G. (2014). Surgical Scheduling: A Lean Approach to Process Improvement, AORN Journal, January 2014 Vol 99 No 1. 147 - 159.

SOARES, P.F. LACERDA, D. FILIPPO, T.; PAIM, R. (2006). Aplicação do Processo de Pensamento da Teoria das Restrições para Melhoria em Processos de Negócios. XXVI Encontro Nacional de Engenharia de Produção (ENEGEP). Fortaleza.

SOUZA, L. B. de (2009). Trends and approaches in lean healthcare, Leadership in Health Services, Vol. 22 Iss 2 pp. $121-139$.

SPEAR, S.J. (2005). Fixing healthcare from the inside, today, Harvard Business Review, Vol. 83, No. 9, pp. 78-91.

STAMM, M.L. NEITZERT, T.R.; SINGH, D.P.K. (2009). TQM, TPM, TOC, Lean e Seis Sigma - Evolution of Manufacturing Methodologies under the Paradigm shift from Taylorism/ Fordism to Toyotism? International Annual Euroma Conference. Gothenburg, Swend.

STEIN, R.E. (1996). Re-Engineering the Manufacturing System - Applying the Theory of Constraints, Marcel Dekker, NY.

WARING , T. S.; ALEXANDER, M. (2015). Innovations in inpatient flow and bed management: An action research project in a UK acute care hospital ", International Journal of Operations \& Production Management, Vol. 35 Iss: 5, pp.751 $-781$.

WARNER, C. J.; WALSH, D. B.; HORVATH, A. J.; WALSH, T. R.; HERRICK, D. P.; PRENTISS,S. J.; POWELL, R. J. (2013). Lean principles optimize on-time vascular surgery operating room starts and decrease resident work hours. Journal of vascular surgery [0741-5214] Warner, Courtney, vol:58 iss:5 pg:1417 $-22$.

WHITSON, D. (1997). Applying just-in-time systems in health care, IIE Solutions, Vol. 29 No. 8, pp. 32-7.

WOMACK, J. P.; JONES, D. (1994). From Lean Production to the Lean Enterprise. Harvard Business Review.

WOMACK, J. P.; JONES, D. (1996). Lean thinking: Banish Waste and Create Wealth in your Corporation. FREE PRESS. New York.

WOMACK, J. P.; JONES, D. (2004). A Mentalidade Enxuta nas Empresas Lean thinking: Elimine o Desperdício e Crie Riqueza. Editora Campus.

ZIDEL, T. (2006). A lean Guide to Transforming Healthcare: How to Implement lean Principles in Hospitals, Medical Offices, Clinics, and other Healthcare Organizations, Quality Press, Milwaukee, WI. 